\title{
THE INFLUENCE OF ENGLISH MEDIUM INSTRUCTION ON TEACHER IDENTITY
}

\author{
K.N. Volchenkova ${ }^{1}$, volchenkovakn@susu.ru, \\ A.Ph.Bryan', tonypbryan@yahoo.co.uk \\ ${ }^{1}$ South Ural State University, Chelyabinsk, Russian Federation, \\ ${ }^{2}$ University of Bath, Bath, United Kingdom
}

\begin{abstract}
For a content teacher who is a non-native English speaker, the transition from giving instruction in one's own native language to teaching in English is potentially challenging. This paper examines the impact of English-Medium Instruction (EMI) on the professional identity of academic staff based on the research conducted at South Ural State University. Authors analyze the Russian context of EMI introduction into tertiary education, define the concepts: "identity", "professional identity", "teacher identity" and adapt the identity components (professional, personal, institutional) offered by Kling Soren to SUSU faculty. Teacher cognitions of their own authority, expertise and identity are captured using qualitative methods including observation and interview. By following a cohort of teachers through the initial stage of EMI training and examining their self-perceptions before training, the study examines the initial state of this identity and the impact of the EMI training on it. The results show that though the SUSU faculty perceive the process of EMI introduction at SUSU as inevitable one, they realize the opportunities and the needs for professional development, both in the field EMI strategies and English language proficiency with professional expertise being threatened. Results of this research can be used as for development of language policy of higher education institution in the field of foreign-language education, and for development of programs of professional development in the field of EMI.
\end{abstract}

Keywords: internationalization, English medium instruction, identity, teacher identity, professional identity, personal identity, institutional identity.

\section{Introduction and purpose}

Changes introduced into the system of tertiary education and caused by globalization and internationalization of higher education affect the academic profession both positively and negatively. Academic staff have to acquire new roles and expand their competences but the pace of the changes and scarce time resources often aggravate the academic faculty cognitions and frustrate the faculty. Thus, it is of paramount importance to find out how the university community of practice perceive the internationalization and Englishization of tertiary education and what impact these processes have on academic identities as the changes going on can affect teachers' performance, motivation and efficacy $[2,30]$.

Scientists recognize that an institution will become internationalized "only through the creative utilization of the imagination and agency of those who comprise the university" [26]. Therefore, the academic staff are the central subjects of internationalization, operating this process [22] and being influenced by the consequences of this phenomenon [15].

One of the drivers of internationalization is the wide introduction of English taught programmes. There is irrefutable evidence that English as a medium of instruction (EMI) is a global phenomenon nowadays, as the majority of higher education institutions go global and strive for attracting both international students and academic staff to increase their international profiles [25]. Therefore, the academic identity should be given special attention as the integration in global science and education depends on the cognitions of the academic staff, their affinity to the values of internationalization and their commitment in time and effort to university Road maps.

Much research has been conducted to define the concept of identity [3]; to establish the nature of identity, self and agency [13, 14]; to describe identity as both the process if "reinventing" yourself and the result of this process that teachers experience [19]; to study the social and contextual factors that affect the teacher's perception of himself in profession and in professional society [10]. However, few researchers investigate the impact of EMI on all the constituents of teacher identity. Reaching a full understanding of the important aspects of identity and the ways in which they are 
related can be challenging, though they are essential to find out the ways to support the academic staff to successfully perform their new roles on international arena.

The focus of our research is to define how the changes in tertiary education, in particular, the introduction of EMI programmes affect the teacher's identity when a lot of pressure is put on academic staff to internationalize both their education practices and research activities. The purpose of this paper is to provide evidence that the introduction of EMI programmes affects all the constituents of teacher identity in various ways by discovering the particular aspects of the influence at a certain EMI setting that is Russian Federation, South Ural State University. The data gained will help to structure the teacher training programmes in EMI to provide substantial support to content teachers and to strengthen their professional and personal identities.

\section{The Russian context of EMI}

The Russian context of EMI has its own distinctive aspects. First, it is tremendously diverse. At Innopolis, Kazan, a computer technology university, the default teaching language is English even though the great majority of students are Russian; with well-paid faculty members and many NNESs that have fluent English. Students are supposed to have upper-intermediate level of English (CEFR B2). In this context, EMI training risks being misinterpreted by faculty members as an unnecessary remedial activity. However at SUSU, the site of our study, the default teaching language is Russian, only a limited number of faculty members speak fluent English, and there is no fixed minimum level of English for students, even those enrolled on SUSU's Englishmedium courses. Translation into English, and proofreading of articles written by faculty members, are regarded as valuable services, which the university provides through a writing centre.

A second important aspect is the disciplinary mix of Russian higher education. The old Sovietera image of research strongly oriented to subjects like Physics and Engineering may have faded, but the preoccupation with technology has continued in a new form. The potentially wide applications of machine learning, together with the global success of American tech companies, provides the background to public-private partnerships such as Innopolis. For the current government, artificial intelligence is one of the key technologies of the future, and the dominant lan- guage in Computer Science is English. SUSU's origins lie in the natural sciences and engineering, and analysis of the university's strategic plan demonstrates that technology is a strong element in its discourse of modernization. We might hypothesize that at SUSU, support for teaching in English will be stronger in science, technology, engineering and mathematics. A related question is whether disciplinary background affects willingness to act as both language and content teacher. Our respondents' cognitions of their own responsibilities for language teaching form one element of our study.

Thirdly, we must consider the cultural and political contexts. We must not forget that Russian is also an international medium of instruction. RMI has been one of the casualties of the collapse of the Soviet Union. In Kazakhstan, Fierman [9] has found evidence of English being used more widely at the expense of Russian. In addition, Lillis and Curry [17] have demonstrated that NNES academics face the challenge of an international academic publishing industry heavily biased towards native speaker English. At SUSU, English-language publication targets have been imposed on staff across the board with little regard for previous experience or language proficiency, based largely on the hope that translation services can bridge the gap. All these factors could foster resentment of the priority given to English. Contrastingly, other English-language modernization policies are potentially more appealing to teachers, and might provide a basis for what Dewi [7] has labelled "positive imperialism". SUSU's strategy of internationalizing by offering more courses in English offers a crucial career development opportunity to the lecturers who deliver them. Most are low-paid by international standards. These rival perceptions of the rise of English as a symptom of Russian cultural decline or as a symbol of openness and opportunity can also be observed at national level. In 2012, the positive view of English informed Project 5-100, a modernization programme for higher education in which SUSU participates. More recently, as relations with Anglophone countries have deteriorated, a new Minister of Education, less sympathetic to 5-100, has taken over and has introduced Russian language tests for foreign students wishing to study in Russia. Perhaps some rebalancing after the rise of IELTS and TOEFL was overdue. In summary, then, the place of the English language in Russia is perhaps even more contentious than in other expand- 


\section{Теория и методика профессионального образования}

ing circle countries. The cognitions of Russophone teachers about the place of English in Russia are therefore of great interest to us.

\section{South Ural State University context}

The context of our research is South Ural State University, Chelyabinsk, Russia. It is a National Research University, participant of the Project 5-100 aimed to increase the world recognition of Russian universities and to enhance their competitiveness at the world education market. The university comprises 10 higher Schools and Institutes with 120 departments, 40,000 students, more than 250 education programmes with only 8 of thembeing EMI programmes, $100 \%$ of which are Master's programmes in the fields of Linguistics, Economics, Computer Science, Mechatronics, Power Engineering. The university strives to enhance its international profile and makes it a priority to increase the number of EMI programmes that are $100 \%$ English taught programmes aimed to attract international students. Therefore, EMI is here to stay and academic staff can not ignore it but have to commit time and effort to meet the tightening requirements of the administration to the faculty's professional competences.

\section{Defining teacher identity}

With the variety of definitions of identity in the research literature today it is difficult to give a precise description of the concept "identity". For the purposes of our research, the general construct of identity should be contextualized both in terms of the changes taking place in tertiary education and at South Ural State University, in particular, and, in terms of EMI practices being the global trend for universities worldwide.

A major constraint in understanding identity is a variety of issues embodied into the concept. To operate the concept wisely a researcher should understand the link between identity and the self, the connection between identity and agency, the role of emotion, professional discourse in shaping identity, the contextual factors that change identity and the global trends leading to the changes in the system of tertiary education. Moreover, the fact that the concept of identity has been explored across different disciplines: in philosophy $[23,18]$; in psychology [8]; in anthropology [14] adds difficulty to identity comprehension.

In contrast to early modernist definitions that viewed identity as individual and intertwined with the relationship of the concept of self $[8,18]$, a new post-modern construction finds that identity is not a fixed, predetermined attribute, but is in constant flux, changing and shifting with our interaction with our environment and context [1]. The literature on teaching reveals that a teacher's identity is a dynamic notion affected by a number of factors both internal [20], and external [10,21].

A fundamental element here is the importance of agency in identity formation. Van Lier [24] notes that such agency includes initiative, intentionality, control, self-regulation, and selfefficacy. In differentiating self and identity, he states that the self entails a stable core with the aim to preserve one's integrity, while identity negotiates with the surrounding reality to build one's self into the world.

Identity is a context dependent notion and is bound to social, cultural and political contexts. Bucholtz \& Halldefine identity as "the social positioning of self and other; a relational and sociocultural phenomenon that emerges and circulates in local discourse contexts of interaction rather than as a stable structure located primarily in the individual psyche or in fixed social categories" [6, p. 586].

Related to this idea of social nature of a human being is Wenger's [27, 29] concept of communities of practice that are "groups of people who share a concern, a set of problems, or a passion about a topic, and who deepen their knowledge and expertise in this area by interacting on an ongoing basis" $[28$, p. 4]. Wenger admits that identity is formed while engaging in communities of practice. Being the members of these communities, "we define who we are by what is familiar, what is foreign, by what we know and, what we can safely ignore" [28, p. 239].

Moreover, this interaction with the communities of practice, which also involves language and discourse, plays a role in identity construction with an individual being placed in a particular context [11]. Gee [12] defines identity as a certain kind of person in a given context. He outlines four perspectives of the identity: 1) the nature perspective (N-Identities): a state developed by forces in nature (e.g. gender); 2) the institution I-perspective (I-identities): a position that stems from authoritative powers within institutions (e.g. a professor); 3) the discursive perspective (D-identities): an individual trait that develops through interaction with others (e.g. caring); and 4) the affinity perspective (A-identities): identity that develops based on experiences shared with a like-minded group (e.g., teachers). Thus, people 
have to manage not one single unity but multiple identities the manifestation of each depends on the time, place and context.

Beijaard et al. $[4,5]$ conceived teacher identity as an ongoing process of reflection on teachers' practical experiences and identified four critical features for growing a professional identity: professional identity is an ongoing, dynamic process in which teachers interpret and reinterpret their experiences; it implies both person and context; professional identity consists of several sub-identities that strive to live in harmony with one another; the drive of identity is agency, as teachers themselves should be active in their professional development.

Thus, accumulating the definitions and aspects discussed above teacher identity can be described as a complex phenomenon, an ongoing self-directing process and the result of the process, comprising a set ofdynamic and flexible sub-identities developed in time having highly-contextualized nature and depending on social conditions and professional circumstances of an individual.

The social nature of teacher identity explicated by an idea of belonging to a particular community applies to the participants of our study as the academic staff enter a new job description as EMI lecturers, acquire new roles, expand beyond their boundaries, engage in new communities and have to negotiate meaning with international students, administration of the university, language teachers, English taught programme heads. The identity teachers have in the workplace, in this case as academic lecturers at a university and their affiliation within their field of study, or even affiliation with those who use English as the medium of instruction, plays a role in how these teachers define themselves and how the changes introduced affect their professional and personal conceptions of self.

\section{Teacher identity structure}

To evaluate the impact of English medium instruction onto the academic staff identity we have to describe the structure of teacher identity.

Describing the structure of identity, researchers in fact disclose its content. Eriksson [8] determines the content of identity as a configuration, which unites inclinations, basic needs, abilities, significant self-identifications, successful sublimations and constant roles. It also determines the system of values, ideals, vital plans, social roles of an individual, its inclusiveness in current life of society.
The typology of identity shifts discussion from the content of identity to the form of its expression and confirms a variety of different types (an ego identity and group identity, personal and social, positive and negative, acquired, borrowed, premature, mature) identities expressing polysemy of its contents and discloses need of their allocation by various researchers.

The idea about the existence of two main aspects of identity - focused on a social environment (social identity) and on unique manifestations of the person (personal identity) - is prevailing in modern western psychology. It gives rise to two principal types of structural classifications of identity: the first type is based on the need in self-realization and concentrated on personal motives, values, attitudes. The second type of classification is focused on the need in recognition and here the principle of classification lies into the idea of belonging to a community of practice and how the others see me.

We adopted the model of teacher identity from J. Kling Soren's study [16]. She describes the teacher identity as a construct consisting of three components: professional identity, personal identity and institutional identity. The model is presented on Fig. 1.

Professional identity comprises two elements: "professional expertise, which is interpreted in relation to the specific knowledge teachers acquired and professional authority, which is interpreted as how others see you, in relation to what you know and your status" [16, p. 82]. Based on lecturers' cognitions, Kling found that professional expertise consisted of two components, content knowledge and pedagogical knowledge. The latter has a variant, content pedagogical knowledge, which is the pedagogical knowledge need to teach a specific subject. Professional expertise embraces professional authority, which means whether your expertise is recognized and accepted by others. When we consider that teaching in English affects terminology, pedagogy and ability to communicate expertise, it is easy to see how EMI might call into question a teacher's professional identity, that is, their sense of self as a professional person.

Personal identity includes the features of character the person possess and manifests in the classroom. They can be both positive and negative and "they can affect all aspects of what we do, how we react to a variety of situations, and how we are perceived" [16, p. 90]. Aspects of personal identity can form an element of 


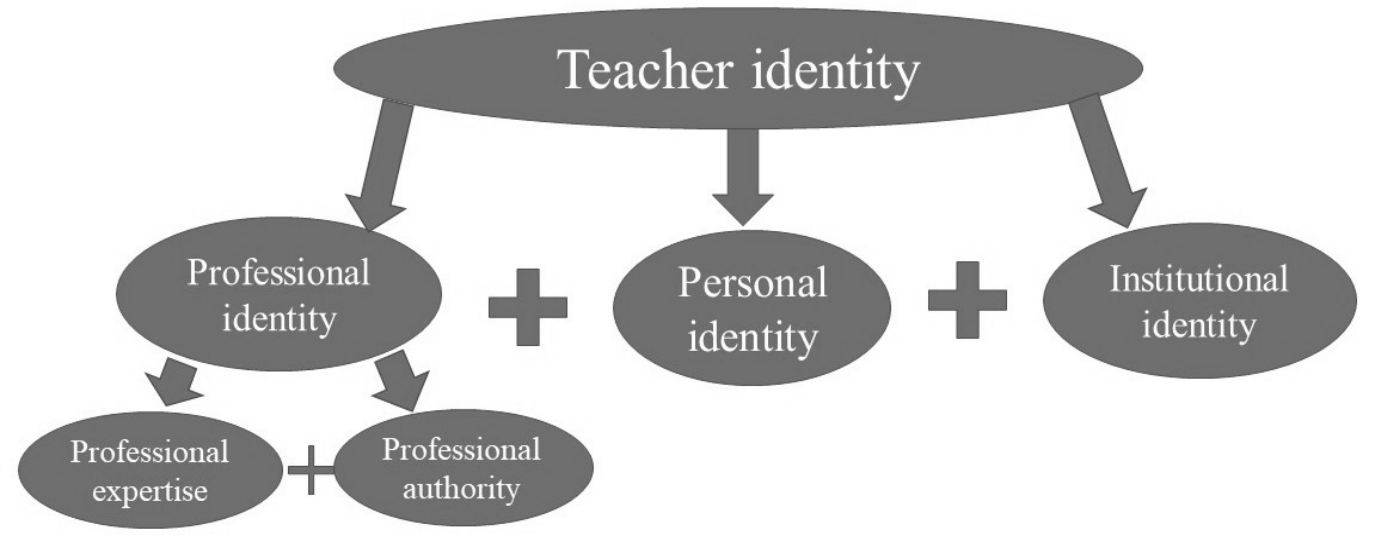

Fig. 1. Kling's model of teacher identity

teacher identity, for example if one sees oneself as a hardworking person, committed to changing society, or interested in other cultures.

Institutional identity is "a form of hierarchical position in the academic community" [16, p. 139]. This describes the sense and degree of affinity someone feels for the institution they belong to, such as whether they identify with the institution's goals, for example internationalisation.

These three components, professional identity, personal identity and institutional identity, collectively constitute teacher identity in its various dimensions.

We have also adopted our conceptual framework for our qualitative study of teacher cognitions of their identity in EMI settings. Teacher cognitions are teachers' beliefs about teaching. These beliefs can be elicited through questionnaires, interviews and reflective writing or inferred from observations. Kling [16] used teacher cognitions as one of the bases for her conceptualization of teacher identity.

Thus, after describing the concept and structural elements of teacher identity we can formulate the research questions the study seeks to answer.

Research question 1: What are South Ural State University EMI lecturers' attitudes to EMI?

Research question 2: What is the baseline for SUSU EMI teaching staff before the systematic introduction of EMI?

Research question 3: How does EMI influence the constituent parts of a teacher identity?

\section{Methods and procedure}

The baseline research was aimed to find out the initial setting of EMI at SUSU, to reveal the teaching staff attitudes and cognitions of what EMI is, to define the possible threats and possi- bilities for a teacher identity as a flexible multicomponential construct. The study was conducted at South Ural State University, springautumn 2017.

The need to introduce EMI in the education process has become the motivation for the development of the tailored language support course for the university staff chosen to provide teaching in English in the nearest future. The staff enrolled has become our respondents. All are the participants of Lingvaprogramme - language support courses for the university staff developed on a modular principle, and provided by the university on a regular basis.

A questionnaire and a survey were devised to study academic staff cognitions on the EMI introduction into SUSU.

The questionnaire comprised 15 questions about the respondents' affiliation, teaching experience, experience in EMI, their ideal image of a teacher and their ideas about the influence of EMI on teaching process where their roles are those of content teachers. We also questioned them on effective teaching strategies for an EMI classroom.

The Likert scale survey consisted of 40 statements that allowed us to analyze the participants perceptions of possible benefits and drawbacks of EMI for SUSU, the institutional context of EMI, the EMI motivation of the SUSU staff, their confidence in own expertise and effectiveness in EMI teaching.

Initially the participants were asked to assess their level of English according to the CEFR (Common European Framework of Reference). The description of CEFR levels were given to them and they marked the levels of four basic skills: speaking, listening, writing and reading. Later on, the participants were given to fill in 
the questionnaires about their position at university, experience in EMI, background in language learning. Finally, the respondents were to answer the questions on their how they percept EMI, what challenges and possibilities they see for EMI introduction at SUSU.

\section{Participants' Profile}

The participants of the study were 30 university instructors, associate professors, and professors from 14 different departments: Computer Science, Engineering, Mechatronics and Automation, Civil Engineering, Motor Transport, Architecture, Biology, Structural Chemistry, Law, Philosophy, Sociology and Political Sciences, Economy and Management, Customs Affairs, Automated Electric Drive. None of the participants has taught or has been taught abroad, and none of them has a clear idea of what EMI is. Most of them do percept EMI as reading lectures in English by direct transfer of their content knowledge from Russian into English not taking into consideration the pitfalls of the process and the context of its application as well as the multicultural issues that may arise in the classroom.

\section{Results}

1.1. Self-assessment of English proficiency and EMI experience

The self-assessment results show that 53\% report Intermediate level of English in speaking, writing, listening, and reading, with the receptive skills rated higher than the productive. Most participants also say that they are not very often in contact with English, in terms of the four skills. $47 \%$ assessed themselves as Upper-Intermediate users of English though all of the participants admitted they have difficulties of self-expression and stumble on both Grammar and Vocabulary issues every time they use English.

A fifth of the respondents $(20 \%)$ have had one year of experience in EMI, and all of them had it with international students (not local students) at South Ural State University without leaving Russia. The reflections on EMI experience are very contradictory starting from euphoria remarks (quite few in number) to the description of EMI as a challenging task. The correlation with language ability is obvious here the higher the standard of English the more positive feelings the participants had. Those who do struggle with the language admitted that it was a frustrating experience for them as there were situations in the classroom when they did not get whether the students understood them and did not know the strategies how to check comprehension with a limited language ability of both teachers and students. All 30 participants (100\%) admitted they needed additional training in both language and teaching strategies for the successful implementation of EMI.

The answers to the question: How did you feel when delivering classes in English can be illustrated by the following answers of the participants: "Embarrassed", "Not confident", "Less confident than in Russian". "It is a challenge that you have never had before". A positive response was made by a philosopher that has C1 (Advanced level of English). "On the one hand, it was a wonderful intercultural atmosphere of genuine intercultural communication when a Russian teacher and Iraq students read and analyzed the text of French philosopher translated into English. On the other hand, it was hard to concentrate on the content as I often caught myself on the thought that I am thinking about the grammar issues".

\subsection{The impact of EMI on academic staff} institutional identity

It can be admitted that EMI for SUSU staff is a new phenomenon and an emerging field of study. Though $100 \%$ of teachers accept it as an inevitable development of the university, $83 \%$ notify the fact that SUSU staff needs language support courses to raise their level of proficiency in English (Table 1). Moreover, the respondents express the wish for the international students to be tested for their language ability before being enrolled - the procedure that is neglected now with the university language policy undefined.

Language ability is the main concern for Russian teachers if to compare with the research conducted in Scandinavian countries and it definitely influenced their opinions, when $73 \%$ agree that students learn better in their mother tongue though $60 \%$ support the statement that better course material is available in English.

$67 \%$ of the respondents is for the introduction of the English taught courses in the department programmes as they see it as the main reason for attracting international students and visiting professors for international cooperation and sharing research findings.

Though only $53 \%$ accept it as the responsibility of the department what courses to choose for EMI instruction, we can see that $40 \%$ are not against but uncertain about whose responsibility it is. 
Institutional identity: benefits and drawbacks of EMI

\begin{tabular}{|l|c|c|c|c|c|c|}
\hline \multicolumn{1}{|c|}{ Statements } & $\begin{array}{c}\text { Strongly } \\
\text { agree }\end{array}$ & $\begin{array}{c}\text { Partly } \\
\text { agree }\end{array}$ & $\begin{array}{c}\text { Neither } \\
\text { agree nor } \\
\text { disagree }\end{array}$ & $\begin{array}{c}\text { Partly } \\
\text { disagree }\end{array}$ & $\begin{array}{c}\text { Strongly } \\
\text { disagree }\end{array}$ & $\begin{array}{c}\text { Don't } \\
\text { know }\end{array}$ \\
\hline $\begin{array}{l}\text { Not all university teachers have } \\
\text { the necessary skills } \\
\text { for teaching in English }\end{array}$ & 19 & 6 & 5 & 0 & 0 & 0 \\
\hline $\begin{array}{l}\text { Students learn best when they } \\
\text { are taught in their mother tongue }\end{array}$ & 12 & 10 & 6 & 2 & 0 & 0 \\
\hline $\begin{array}{l}\text { Teaching in English could lead } \\
\text { to a wider gap between students } \\
\text { levels of ability }\end{array}$ & 2 & 17 & 5 & 4 & 0 & 2 \\
\hline $\begin{array}{l}\text { If the course material is in English, } \\
\text { teaching in English creates a better } \\
\text { link between teaching and course } \\
\text { material }\end{array}$ & 6 & 12 & 6 & 2 & 2 & 0 \\
\hline $\begin{array}{l}\text { Better course material is available } \\
\text { in English than in Russian }\end{array}$ & 6 & 12 & 3 & 5 & 2 & 2 \\
\hline
\end{tabular}

\subsection{The Impact of EMI on academic staff} personal identity

Though few of the participants had EMI experience they realize how beneficial it is for their career at the university as the KPI they have to reach include their publication activities, establishing international academic contacts, participating in international research teams and teaching in EMI can substantially improve their standard of English and provide them with the necessary skills. It is a striking change for the last few years in the motivation of the academic staff as the top-down approach to implement English into education process and research activities turned into the personal ambition of being a successful researcher at a university (Table 2).

To reveal the personal identity of the respondents we asked them, first, to draw an ideal portrait of a teacher and the way he/she should be perceivedby the students. Then we suggested re- flecting on the qualities the respondents have and define which ones they still need to develop.

The results show that the majority of the SUSU staff portrays a teacher as a knowledgeable and competent person, ready to help, open to communication, and cooperation with the students.

The features the teachers marked as needed to be improved do mostly reflect their lack of confidence not in the specific domain knowledge but in language proficiency that can influence their behavior in the classroom and even turn them into less sociable people deprived of sense of humor.

The decisive influence of English language proficiency on teacher's personality is proved by the fact that $86 \%$ of the respondents say they feel less confident when they deliver their lectures in English and $60 \%$ say it causes difficulties for them to lead a discussion in English (Table 3).

Personal identity: motivation to teach in English

Table 2

\begin{tabular}{|l|c|c|c|c|c|c|}
\hline \multicolumn{1}{|c|}{$\begin{array}{c}\text { I (am going to) teach } \\
\text { in English because }\end{array}$} & $\begin{array}{c}\text { Strongly } \\
\text { agree }\end{array}$ & $\begin{array}{c}\text { Partly } \\
\text { agree }\end{array}$ & $\begin{array}{c}\text { Neither } \\
\text { agree nor } \\
\text { disagree }\end{array}$ & $\begin{array}{c}\text { Partly } \\
\text { disagree }\end{array}$ & $\begin{array}{c}\text { Strongly } \\
\text { disagree }\end{array}$ & $\begin{array}{c}\text { Don't } \\
\text { know }\end{array}$ \\
\hline The university wants me to & 2 & 6 & 10 & 4 & 5 & 3 \\
\hline My department wants me to & 2 & 6 & 6 & 2 & $\mathbf{1 2}$ & 2 \\
\hline It is a personal ambition of mine & $\mathbf{2 0}$ & $\mathbf{6}$ & 2 & 2 & 0 & 0 \\
\hline Of the benefit to my students & 4 & 4 & 10 & 2 & 10 & 0 \\
\hline $\begin{array}{l}\text { Of the respect it will bring } \\
\text { from my students }\end{array}$ & 4 & 6 & 11 & 5 & 4 & 0 \\
\hline $\begin{array}{l}\text { It will be good for my career } \\
\text { prospects }\end{array}$ & $\mathbf{1 2}$ & $\mathbf{1 6}$ & 2 & 0 & 0 & 0 \\
\hline
\end{tabular}


Personal identity: confidence in one's own effectiveness in EMI

Table 3

\begin{tabular}{|l|c|c|c|c|c|c|}
\hline \multicolumn{1}{|c|}{ Statements } & $\begin{array}{c}\text { Strongly } \\
\text { agree }\end{array}$ & $\begin{array}{c}\text { Partly } \\
\text { agree }\end{array}$ & $\begin{array}{c}\text { Neither } \\
\text { agree nor } \\
\text { disagree }\end{array}$ & $\begin{array}{c}\text { Partly } \\
\text { disagree }\end{array}$ & $\begin{array}{c}\text { Strongly } \\
\text { disagree }\end{array}$ & $\begin{array}{c}\text { Don't } \\
\text { know }\end{array}$ \\
\hline $\begin{array}{l}\text { It is more difficult for me to have } \\
\text { a discussion related to my specialist } \\
\text { field in English than in Russian }\end{array}$ & $\mathbf{9}$ & $\mathbf{9}$ & 3 & 2 & 7 & 0 \\
\hline $\begin{array}{l}\text { I feel less confident when I teach } \\
\text { in English than in Russian }\end{array}$ & $\mathbf{1 1}$ & $\mathbf{1 5}$ & 1 & 3 & 0 & 0 \\
\hline $\begin{array}{l}\text { I feel I am a less successful teacher } \\
\text { when I teach in English than in } \\
\text { my mother tongue }\end{array}$ & $\mathbf{7}$ & $\mathbf{1 2}$ & 5 & 0 & 2 & 4 \\
\hline $\begin{array}{l}\text { My professional authority suffers/will } \\
\text { suffer from teaching in English }\end{array}$ & 2 & 6 & 2 & 8 & 8 & 2 \\
\hline
\end{tabular}

1.4. The Impact of EMI on academic staff personal identity

In terms of professional expertise $67 \%$ of teachers report they are experts in their fields of study and know the terminology in English they still show less certainty about both language proficiency and teaching strategies needed for seminars and lectures. It can be explained by the fact that STEM teachers do not have pedagogical education and their knowledge of teaching methods is not consistent, as it more relies on their self-study than professional help and in-home courses provided by the university (Table 4 ).

The professional authority of the respondents is not undermined by their lack of competence in English and they are perfectly sure that both students and colleagues percept them as highly qual- ified specialists. The repeated melody of the SUSU staff is that it is not valued enough by the university administration, which is seen from the $50 \%$ of the answers placed in the area of uncertainty (Table 5).

\section{Discussion. Kling's model revisited}

The research conducted enabled us to reconsider the Kling model of teacher identity. The model revisited is presented on Fig. 2. One of the most striking findings is the strong personal motivation that respondents have to become EMI teachers. The idea that teachers shape their identities through their own agency is well illustrated by the extent to which they are motivated by personal ambition rather than by institutional pressures. One reason for this is instrumental: teachers

Professional identity: professional expertise

Table 4

\begin{tabular}{|l|c|c|c|c|c|c|}
\hline \multicolumn{1}{|c|}{ Statements } & $\begin{array}{c}\text { Strongly } \\
\text { agree }\end{array}$ & $\begin{array}{c}\text { Partly } \\
\text { agree }\end{array}$ & $\begin{array}{c}\text { Neither } \\
\text { agree nor } \\
\text { disagree }\end{array}$ & $\begin{array}{c}\text { Partly } \\
\text { disagree }\end{array}$ & $\begin{array}{c}\text { Strongly } \\
\text { disagree }\end{array}$ & $\begin{array}{c}\text { Don't } \\
\text { know }\end{array}$ \\
\hline $\begin{array}{l}\text { I have the language proficiency } \\
\text { to teach in English }\end{array}$ & 4 & 6 & $\mathbf{8}$ & $\mathbf{5}$ & $\mathbf{7}$ & 0 \\
\hline $\begin{array}{l}\text { I know the terminology of my subject } \\
\text { in English }\end{array}$ & $\mathbf{4}$ & $\mathbf{1 6}$ & 2 & 4 & 2 & 2 \\
\hline I can lecture effectively in English & 0 & 3 & $\mathbf{1 3}$ & $\mathbf{8}$ & 5 & 1 \\
\hline $\begin{array}{l}\text { I can conduct a seminar effectively } \\
\text { in English }\end{array}$ & 2 & 4 & $\mathbf{1 2}$ & $\mathbf{8}$ & 4 & 0 \\
\hline
\end{tabular}

Professional identity: professional authority

\begin{tabular}{|l|c|c|c|c|c|c|}
\hline \multicolumn{1}{|c|}{ Statements } & $\begin{array}{c}\text { Strongly } \\
\text { agree }\end{array}$ & $\begin{array}{c}\text { Partly } \\
\text { agree }\end{array}$ & $\begin{array}{c}\text { Neither } \\
\text { agree nor } \\
\text { disagree }\end{array}$ & $\begin{array}{c}\text { Partly } \\
\text { disagree }\end{array}$ & $\begin{array}{c}\text { Strongly } \\
\text { disagree }\end{array}$ & $\begin{array}{c}\text { Don't } \\
\text { know }\end{array}$ \\
\hline I am respected by my colleagues. & 6 & 20 & 2 & 2 & 0 & 0 \\
\hline I feel valued by the university. & 5 & 7 & 13 & 0 & 3 & 2 \\
\hline I am respected by my students & 8 & 16 & 0 & 2 & 2 & 2 \\
\hline
\end{tabular}




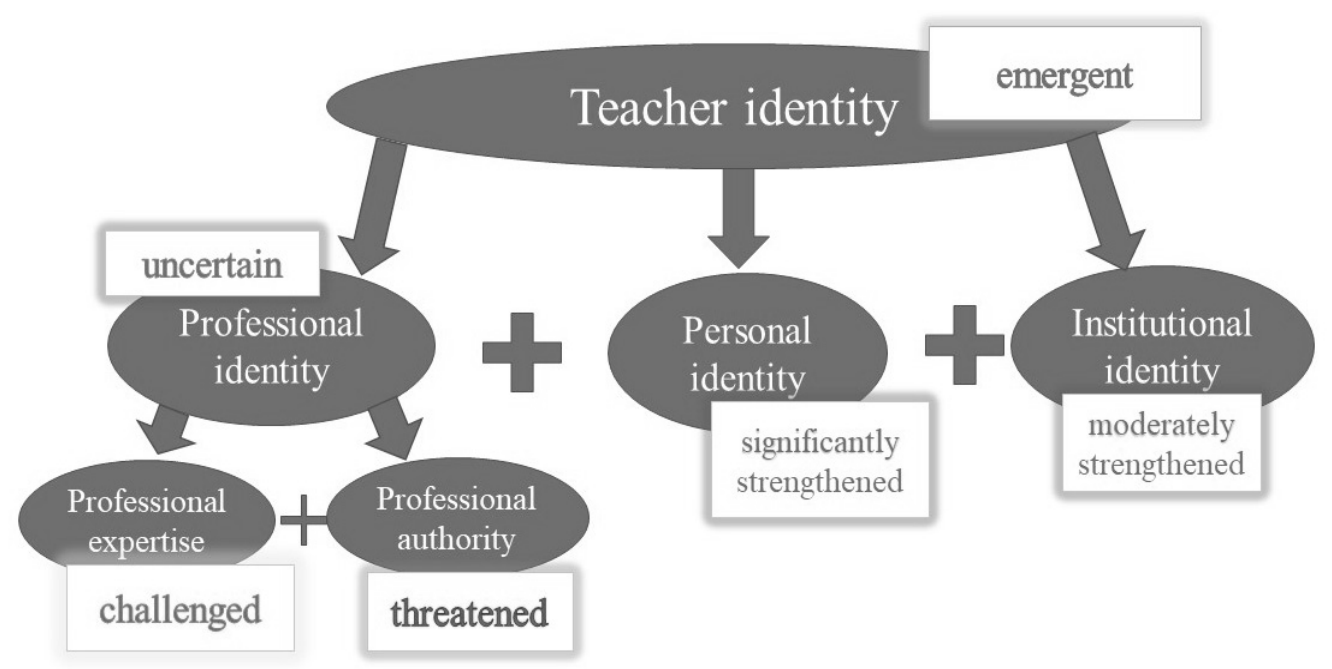

Fig. 2. Kling's model revisited

believe that EMI will be beneficial for their careers. However, there is also a wider nationalcultural dimension, reflected in their majority beliefs in the benefits of English to Russia, and in their openness to Western culture via English.

Concerning professional expertise, our respondents felt confident of their command of the English-language terminology of their subject, but contrastingly unsure of their ability to lecture and conduct seminars in English. Their confidence in whether they are proficient enough in English shows no clear pattern, and so far a majority are not yet convinced that they have sufficient support to bolster their expertise. We can characterize these findings as showing that EMI is a challenge to their professional expertise.

With regard to professional authority, our respondents sent mixed signals. Although a narrow majority of the panel do not expect their authority to suffer when teaching in English, much clearer majorities express concern about their confidence and success using EMI, and a small plural majority do not expect their efficiency to improve. We can perhaps characterize these findings as showing that EMI is somewhat threatening to their professional authority.

Taken together, what we find is that changing to EMI produces uncertainty in our respondents' professional identity, to the extent that it is revealed by their expressed cognitions. This partly reflects their lack of experience of teaching in English, but also stems from doubts about their language proficiency, lack of clarity about their role as content teachers vs. language teachers, and lastly uncertainty about which pedagogical strategies to pursue.

Lastly, although an institutional element to teachers' motivation is less common than personal motives, there is a majority belief that EMI is both necessary and beneficial to the university. To this extent, their sense of institutional identity may be strengthened by teaching in English.

Overall, we have a snapshot of teacher cognitions of identity-related issues at the very start of their training to become EMI teachers. It is clear that there are many elements of teacher identity in play and open to change. For this reason, we could characterize our panel's teacher identities at this stage as emergent.

\section{Conclusions}

The present study explores how the ongoing changes in the system of tertiary education, and EMI introduction in Russian university setting, in particular, impact the academic staff identity as the academic staff is the valuable resource for the university administration to reach their strategic goals set by university Road Maps.

The SUSU case indicates that few EMI programmes are offered currently to attract international students and the academic staff consider EMI programme development as inevitable evolution of the university. They percept it overall as a positive change in their professional career development. The faculty expressed affinity with the university goals in terms of EMI introduction and their institutional authority seemed to be stable. Moreover, they are motivated by personal ambition rather than by institutional pressures. The main challenge here is to bridge the gap between real and desired English proficiency both for EMI lecturers and international students.

The results of the study can be used to develop the theoretical issues of academic staff identity 
based on Kling Soren model of teacher identity. The survey results of SUSU academic staff cognitions about the impact of EMI on their personal, professional and institutional identities can be utilized for both the development of institutional language policies and teacher training courses for content teachers.

\section{References}

1. Akkerman S.F., Meijer P.C. A Dialogical Approach to Conceptualizing Teacher Identity. Teaching and Teacher Education, 2011, no. 27 (2), pp. 308-319. DOI: 10.1016/j.tate.2010.08.013

2. Archer L. The New Neoliberal Subjects? Young/er Academics' Constructions of Professional Identity. Journal of Education Policy, 2008, no. 23 (3), pp. 265-285. DOI: 10.1080/02680930701754047

3. Beauchamp C., Thomas L. Understanding Teacher Identity: An Overview of Issues in the Literature and Implications for Teacher Education. Cambridge Journal of Education, 2009, no. 39 (2), pp. 175-189. DOI: 10.1080/03057640902902252

4. Beijaard D., Meijer P.C., Verloop N. Reconsidering Research on Teachers' Professional Identity. Teaching and Teacher Education, 2004, no. 20(2), pp. 107-128. DOI: 10.1016/j.tate.2003.07.001

5. Beijaard D., Verloop N., Vermunt J.D. Teachers' Perceptions of Professional Identity: An Exploratory Study from a Personal Knowledge Perspective. Teaching and Teacher Education, 2000, no. $16(7)$, pp. 749-764. DOI: 10.1016/S0742-051X(00)00023-8

6. Bucholtz M., Hall K. Identity and Interaction: A Sociocultural Linguistic Approach. Discourse Studies, 2005, no. 7 (4-5), p. 585. DOI: 10.1177/1461445605054407

7. Dewi A. Shifts in NNESTs' Professional Identity: An Impact of Language and Culture Immersion. Asian EFL Journal, 2007, vol. 9, no. 4, pp.111-125.

8. Erikson E. Identity and the Life Cycle. New York, International Universities Press Publ., 1989. $267 \mathrm{p}$.

9. Fierman W. Language and Education in Post-Soviet Kazakhstan: Kazakh-Medium Instruction in Urban Schools. The Russian Review, 2006 , no. 65 , pp. $98-116$. DOI: $10.1111 /$ j.14679434.2005.00388.x

10. Flores M.A., Day C. Contexts which Shape and Reshape New Teachers' Identities: A Multi-Perspective Study. Teaching and Teacher Education, 2006, no. 22 (2), pp. 219-232. DOI: $10.1016 /$ j.tate. 2005.09 .002
11. Gee J.P. Social Linguistics and Literacies: Ideology in Discourses. 2nd ed. New York, Routledge Publ., 1996.

12. Gee J.P. Identity as an Analytic Lens for Research in Education. Review of Research in Education, 2000, no. 25, pp. 99-125. DOI: $10.2307 / 1167322$

13. Harre R. The Singular Self. London, Sage Publ., 1998. 234 p.

14. Holland D., Lachicotte W., Skinner D., Cain C. Identity and Agency in Cultural Worlds. Cambridge, Harvard University Press Publ., 1998. $368 \mathrm{p}$.

15. Huang F. The Internationalisation of the Academic Profession. The Internationalization of the Academy Changes, Realities and Prospects, 2014, vol. 10, pp. 1-21.

16. Kling J.S. Teacher Identity in EnglishMedium Instruction: Teacher Cognitions from a Danish Tertiary Education Context. Linguistics. University of Copenhagen. Faculty of Humanities, 2013, p. 225.

17. Lillis T., Curry M.J. Academic Writing in a Global Context. The Politics and Practices of Publishing in English. New York, Routledge Publ., 2010. 210 p.

18. Mead G. Mind, Self and Society. Chicago, The University of Chicago Press Publ., 1934. $174 \mathrm{p}$.

19. Mitchell C., Weber S. Reinventing Ourselves as Teachers: Beyond Nostalgia. London, Routledge Publ., 1998. 192 p. DOI: 10.4324/9780203454497

20. Rodgers C. The Development of the Personal Self and Professional Identity in Learning to Teach. New York, Routledge Publ., 2008, pp. 732-755.

21. Sachs J. Teacher Education and the Development of Professional Identity: Learning to be a Teacher. Oxford, Routledge Publ., 2005, pp. 5-21.

22. Stohl M. We Have Met the Enemy and He is Us: The Role of the Faculty in the Internationalization of Higher Education in the Coming Decade. Journal of Studies in International Education, 2007, vol. 11 (3-4), P. 359-372. DOI: $10.1177 / 1028315307303923$

23. Taylor C. Sources of the Self: The Making of the Modern Identity. Cambridge, Harvard University Press Publ., 1989. 613 p.

24. Van Lier L. The Ecology of Language Learning: Practice to Theory - Theory to Practice. Available at: http://www.dilit.it/allegati/ Leo\%20van\%20Lier\%20Slides.pdf (accessed 15.15.2018). 


\title{
Теория и методика профессионального образования
}

25. Volchenkova K., Bryan A., Semenova Ya. Journey without Maps: Designing a TeacherTraining Course for English Medium Instruction. EDULEARN18 Proceedings, 2018, pp. 2758-2766. DOI: $10.21125 /$ edulearn.2018.0737

26. Webb G. Internationalisation of the Curriculum: An Institutional Approach. London, Routledge Publ., 2005, pp. 109-118.

27. Wenger E. Communities of Practice: Learning, Meaning, and Identity. Cambridge, Cambridge Univ Press Publ., 1998. 318 p.
28. Wenger E. Communities of Practice and Social Learning Systems. Identity Organization, 2000, no. 7 (2), pp. 225-246.

29. Wenger E., McDermott R., Snyder W.M. Cultivating Communities of Practice. Cambridge, Harvard Business Review Press Publ., 2002. 284 p.

30. Whitchurch C., Gordon G. Diversifying Academic and Professional Identities in Higher Education: Some Management Challenges. Tertiary Education and Management, 2010, no. 16 (2), pp. 129-144. DOI: 10.1080/13583881003757029

Received 20 March 2019

\section{ВЛИЯНИЕ ОБУЧЕНИЯ СПЕЦИАЛЬНЫМ ПРЕДМЕТАМ НА АНГЛИЙСКОМ ЯЗЫКЕ НА ИДЕНТИЧНОСТЬ ПРЕПОДАВАТЕЛЯ}

\author{
К.Н. Волченкова ${ }^{1}$, Э.Ф. Брайан ${ }^{2}$ \\ ${ }^{1}$ Южно-Уральский государственный университет, г. Челябинск, Россия, \\ ${ }^{2}$ Университет г. Бас, г. Бас, Великобритания
}

В статье рассматривается влияние обучения специальным предметам на английском языке (EMI) на профессиональную идентичность преподавателя вуза на основе исследования, проведенного в Южно-Уральском государственном университете. Авторы анализируют контекст внедрения ЕМІ в практику вуза, дают определения понятиям идентичность, профессиональная идентичность преподавателя и описывают компоненты идентичности (профессиональный, личностный, институциональный), адаптированные на основе модели идентичности Клинг Сорен. С помощью опросных методов и метода наблюдения анализируется исходное состояние идентичности преподавателей-предметников по отношение к новому виду профессиональной деятельности. Согласно результатам исследования преподаватели воспринимают процесс внедрения ЕМI в практику ЮУрГУ как неизбежный, осознают возможности и потребности в профессиональном развитии как в области использования стратегий ЕMI, так и в области повышения уровня владения иностранным языком, опасаясь при этом снижения статуса профессионала. Результаты данного исследования можно использовать как для развития языковой политики вуза в области иноязычного образования, так и для разработки программ повышения квалификации в области ЕМI.

Ключевые слова: интернационализация, обучение английскому языку, идентичность, идентичность учителя, профессиональная идентичность, личностная идентичность, институциональная идентичность.

Волченкова Ксения Николаевна, кандидат педагогических наук, заведующий кафедрой иностранных языков, Южно-Уральский государственный университет, г. Челябинск, volchenkovakn@ susu.ru.

Брайан Энтони Филип, доцент, преподаватель центра иностранных языков, Университет г. Бас, г. Бас, Великобритания, tonypbryan@yahoo.co.uk.

Поступила в редакцию 20 марта 20192.

\section{ОБРАЗЕЦ ЦИТИРОВАНИЯ}

Volchenkova, K.N. The Influence of English Medium Instruction on Teacher Identity / K.N. Volchenkova, A.Ph. Bryan // Вестник ЮУрГУ. Серия «Образование. Педагогические науки». - 2019. - Т. 11, № 2. - С. 68-78. DOI: $10.14529 /$ ped190207

\section{FOR CITATION}

Volchenkova K.N., Bryan A.Ph. The Influence of English Medium Instruction on Teacher Identity. Bulletin of the South Ural State University. Ser. Education. Educational Sciences. 2019, vol. 11, no. 2, pp. 68-78. DOI: $10.14529 /$ ped190207 